\title{
Tendency towards violence and social roles: a descriptive study among high school students in Turkey
}

Tugba Caliskan, ${ }^{1}$ Candan Kendir, ${ }^{1}$ Gamze Akyol, ${ }^{1}$ Niels Kjaer ${ }^{2}$ and Azize Güldal ${ }^{1}$

${ }^{1}$ Family Medicine Department, Dokuz Eylul University Faculty of Medicine, Izmir, Turkey (Correspondence to: T. Caliskan: tugbacaliskandr@gmail. com). ${ }^{2}$ Research unit for General Practice, Institute of Public Health, University of Southern Denmark, Denmark.

\begin{abstract}
Background: Violence affects more than half of women worldwide and the perception of social roles has a significant role in this. Adolescence is a sensitive developmental period in the life of an individual. It is therefore important to understand the perception of violence and change the acceptance of violence among adolescents.

Aims: To address the experiences that adolescents had with violence and its relationship with attitudes towards women. Methods: This descriptive study, comprising 2321 high school students, was conducted in Izmir, Turkey, between May and August 2015. We used a questionnaire to collect data on sociodemographic information and the perceptions that adolescents have of violence. The Violence Tendency and Attitudes Towards Women Scales were applied to show the perceptions of adolescents of social roles.
\end{abstract}

Results: One third of the adolescents reported that they were exposed to some kind of violence. More than half had witnessed violence against their family members, relatives, or close friends. Conservative and traditional attitudes towards women were associated with a higher tendency towards violence among adolescents.

Conclusions: To end violence against women, public health actions should focus on the young population and their representation of social roles.

Keywords: adolescents, public health, social roles, violence against women, women health

Citation: Caliskan T; Kendir C; Akyol G; Kjaer N; Güldal A. Tendency towards violence and social roles: a descriptive study among high school students in Turkey. East Mediterr Health J. 2021;27(6):563-570. https://doi.org/10.26719/2021.27.6.563

Received: 17/02/20; accepted: 11/08/20

Copyright (c) World Health Organization (WHO) 2021. Open Access. Some rights reserved. This work is available under the CC BY-NC-SA 3.0 IGO license (https://creativecommons.org/licenses/by-nc-sa/3.o/igo)

\section{Introduction}

Violence can affect the life of an individual and result in long-term mental, physical, reproductive and sexual consequences, along with behavioural changes. The consequences may vary from post-traumatic stress disorder to chronic disease, unintended pregnancy, brain injury, or even death $(1,2)$. According to the National Violence Against Women Survey in the United States, $43.4 \%$ of women and $54.3 \%$ of men have experienced some type of violence as a child or adolescent $(3,4)$. The survey reported psychological, physical and sexual violence that varied from bullying to homicide and from teen-dating violence to intimate-partner sexual violence.

In a study by Craig et al., crossnational profiles of violence were studied in 40 different countries, and showed that women were subjected to violence more than men were (5). Furthermore, according to a report by the World Health Organization (WHO), 1 in 3 women (35\%) experience some sort of violence at least once in their lifetime (6). A multinational study by WHO on women's health and domestic violence against women found that women aged 15-19 years were at a higher risk of repetitive violence when compared with older women (1). The prevalence of violence among women in Peru was
$41 \%$ among those aged $15-19$ years versus $8 \%$ for those aged 45-49 years.

Adolescence is a sensitive developmental period in the life of an individual. It is therefore important to understand the perception of violence and change the acceptance of violence among adolescents. It is known that acceptance of violence is associated with varying factors, such as past exposure to violence, violence in the home, parental socioeconomic difficulties, cultural and social beliefs about the masculine and feminine social roles, and lack of job opportunities $(7,8)$.

Violence against women is a social, cultural and public health problem among both adults and adolescents in Turkey, as well as in most, if not all, other countries. In Turkey, $38 \%$ of women are exposed to violence during their lifetime according to data from the 2015 National Violence against Women Survey (9). Women reported that the most common reasons for violence were problems with their partner's family, men-related issues, and economic reasons. Men reported economic issues as the main reason. The survey also showed that children and adolescents who have witnessed violence in the past were vulnerable to violence in adulthood (9).

A study by Celbiş et al., which examined 1175 high school students in Eastern Turkey, found that during 
the previous 12 months, $24.5 \%$ of students had been in a physical fight and $4.3 \%$ had carried a weapon on school property (10). Another study of high school students by Yavuz et al. found that $10 \%$ of students were exposed to violence. Girls mostly experienced violence in the family, whereas boys mostly experienced violence at school. Yavuz et al. argued that the prevention of violence was possible with an increase of awareness in adolescents, determination of risk factors in the family, and additional support to adolescents who were exposed to violence and/or exhibited violent behaviour (11).

The aim of this study was to explore perceived violence, exposure and tendency towards violence, and perspectives on social roles among adolescents in Western Turkey.

\section{Methods}

\section{Study design and setting}

This cross-sectional descriptive study was performed between 1 May and 1 July 2015, in high schools located in Izmir, Turkey. A total of 2321 students from 30 high schools were included based on the criteria for cluster sampling techniques (12). A questionnaire was administered by the authors to the students while they were in class.

In order to calculate the necessary number, a power analysis was performed. There were 40209 students in their final year at high school (provided by official authorities at izmirmeb@gov.tr). There were 300 public and 66 private schools. For this calculation, 40000 grade 12 high school students were used, in 30 clusters, with $50 \%$ prevalence of outcome variable, a \pm 3 confidence interval, 95\% confidence level, and design effect of 2.0. As a result of this calculation, the minimum necessary sample size was determined as 2310 students. To ensure a minimum sample size, 2 classes were chosen from each school, assuming an average class size of 20-30 students. For this purpose, the 366 schools were arranged in alphabetical order, starting with a random school, and 30 schools were selected by systematic sampling with 13 intervals.

\section{Data collection}

Data were collected using a questionnaire that combined 2 sections created for this study, along with 2 other sections that had already been created and tested for validity and reliability in previous studies. In the first part, sociodemographic information such as sex, age and socioeconomic status of students, and parental education levels was collected. In the second part, data on experiences of violence and the thoughts of the students about the types of and reasons for violence were collected. Their experiences of violence were inquired about using "Have you ever experienced ..." likert-type questions, with possible answers as never, rarely, sometimes, usually, and always. The thoughts of the students about violence were categorized as physical, emotional, economic, restriction of human relationships with others, sexual, verbal, and other, and multiple answers were possible. Reasons for vio- lence were also categorized and the students were free to choose more than 1 response. These categories were disrespect towards men, riposte against men, income conflicts, honour troubles, alcohol use, psychological problems, and other. The third part consisted of the Violence Tendency Scale (VTS). The VTS was originally developed in Turkish by Haskan and Ylldırım in 2012, and it consists of 20 items and includes 4 factors, comprising the feeling of violence, violence through information technologies, feeling of harming others, and using violence against others. In the study of Haskan and Yildırım, the Cronbach $\alpha$ of the scale was measured as 0.87 and the test-retest reliability factor was 0.83 (13). The fourth part consisted of the Turkish version of the Attitudes towards Women Scale (AWS), which was developed by Spence et al. in 1973 (14). The validity and reliability of the Turkish version, which comprised 15 items, was assessed in 2013 (15). In this study, Cronbach $\alpha$ was determined as 0.81. A high score indicated a profeminist (advocacy of women's rights on the grounds of equality of the sexes) egalitarian attitude and a low score indicated a traditional, conservative attitude. The first two authors visited all of the selected classes in person in the selected schools, and ensured that all of the attending students who were present in the classroom answered the questionnaires. However, some students were absent due to illness or other reasons. The head teachers of the classes estimated the average absence rate to be $<5 \%$.

\section{Data analysis}

The statistical analysis was performed using SPSS version 21.0 (IBM Corp., Armonk, NY, USA). Means and

\begin{tabular}{|c|c|}
\hline \multicolumn{2}{|c|}{$\begin{array}{l}\text { Table } 1 \text { Sociodemographic features of participants and } \\
\text { awareness of types of violence among adolescents }\end{array}$} \\
\hline & No./total (\%) \\
\hline \multicolumn{2}{|l|}{ Sex } \\
\hline Female & $1255 / 2321(54.1)$ \\
\hline Male & $1066 / 2321(45.9)$ \\
\hline \multicolumn{2}{|l|}{ Economic status } \\
\hline Low & $115 / 2321(5.0)$ \\
\hline Middle/high & $2206 / 2321(95.0)$ \\
\hline \multicolumn{2}{|l|}{ Maternal education level } \\
\hline Lower than high school & $1187 / 2321(51.1)$ \\
\hline High school or higher & $1134 / 2321(48.9)$ \\
\hline \multicolumn{2}{|l|}{ Paternal education level } \\
\hline Lower than high school & $995 / 2321(42.9)$ \\
\hline High school or higher & $1326 / 2321(57.1)$ \\
\hline \multicolumn{2}{|l|}{ Types of violence } \\
\hline Physical & $2144 / 2321(92.4)$ \\
\hline Verbal & $1878 / 2321(80.9)$ \\
\hline Emotional & $1849 / 2321(79.7)$ \\
\hline Sexual & $1828 / 2321(78.8)$ \\
\hline Restriction of social interaction & $1197 / 2321(51.6)$ \\
\hline Economic & $1010 / 2321(43.5)$ \\
\hline
\end{tabular}


standard deviations were calculated for the continuous variables. Frequencies and percentages were calculated for the categorical variables. $\chi^{2}$ test and analysis of variance were used to analyse relations between the dependent and independent variables. Stepwise multiple logistic regression was performed using $\mathrm{R}$ version 1.1.383. $p<0.05$ was considered to be statistically significant.

\section{Permissions/ethical considerations}

Ethical approval was obtained from the Dokuz Eylul University Faculty of Medicine Non-Invasive Research Ethics Committee and permission was authorized by the Izmir Division of the National Ministry of Education.

\section{Results}

The total number of participants was 2321 and the response rate of the students attending class on the day that the questionnaire was administered was $100 \%$. The mean age was 17.13 ( 0.62 ) years (range: $15-20$ years). Table 1 displays the sociodemographic features and awareness of the types of violence among the adolescents. Among the adolescents, 45.9\% $(n=1066)$ were male, 95\% ( $n=2206)$ had middle or high economic status, $51.1 \%(n=1187)$ had a mother with lower than high school education, and 42.9\% ( $n=995)$ had a father with lower than high school education. Physical violence was the type most known by the students at a rate of $92.4 \%(n=$
2144), while economic violence was less known at a rate of $43.5 \%(n=1010)$.

Among the participants, $45 \%(n=1044)$ had taken part in some kind of attempted violence directed towards their family members, relatives, or close friends, and $38.7 \%$ ( $n=898)$ had experienced some kind of violence directed towards themselves by their family members, relatives, or close friends (Table 2). Moreover, 57.7\% (n $=1340$ ) had witnessed violence directed towards their family members, relatives, or friends by others and $57.4 \%$ ( $n=1331)$ had witnessed attempted violence towards their family members, relatives, or friends by others.

Psychological problems $(78.8 \% ; n=1830)$ and alcohol use $(76.4 \% ; n=1774)$ were considered as the reasons for violence towards women by most of the students. Disrespect and insults against men were stated as reasons by a smaller number of students, but the percentage was still $27.1 \%(n=628)$. Honour issues were mentioned by $57.5 \%(n=1334)$ of the adolescents and $40.6 \%(n=943)$ mentioned income conflicts.

The mean VTS and AWS values were 47.23 (10.68) and 40.07 (6.43), respectively. There was a significantly negative relationship between the VTS and AWS scores $(\mathrm{r}=-0.310, P<0.001)$. The relationships of these values with the demographic features and knowledge of the types of violence are presented in Table 3. Adolescents who had a low economic status had significantly higher VTS scores $(P<0.001)$ and lower AWS scores $(P<0.001)$. The education

\begin{tabular}{|c|c|c|c|c|}
\hline & & No./total (\%) & & n (\%) \\
\hline \multirow{5}{*}{$\begin{array}{l}\text { Took part in violence directed towards family } \\
\text { members, relatives, or friends }\end{array}$} & Yes & $1044 / 2321(45.0)$ & Rare & $691(29.8)$ \\
\hline & & & Sometimes & $221(9.5)$ \\
\hline & & & Often & $55(2.4)$ \\
\hline & & & Very often & $77(3.3)$ \\
\hline & No & $1277 / 2321(55.0)$ & & \\
\hline \multirow{5}{*}{$\begin{array}{l}\text { Violence attempts received from family } \\
\text { members, relatives, or friends }\end{array}$} & Yes & $898 / 2321(38.7)$ & Rarely & $613(26.4)$ \\
\hline & & & Sometimes & $177(7.6)$ \\
\hline & & & Often & $61(2.6)$ \\
\hline & & & Very often & $47(2.0)$ \\
\hline & No & $1423 / 2321(61.3)$ & & \\
\hline \multirow{5}{*}{$\begin{array}{l}\text { Observed attempted violence directed towards } \\
\text { family members, relatives, or friends }\end{array}$} & Yes & $1340 / 2321(57.7)$ & Rarely & $770(33.2)$ \\
\hline & & & Sometimes & $364(15.7)$ \\
\hline & & & Often & $104(4.5)$ \\
\hline & & & Very often & $102(4.4)$ \\
\hline & No & $981 / 2321(42.3)$ & & \\
\hline \multirow{5}{*}{$\begin{array}{l}\text { Observed attempted violence towards family } \\
\text { members, relatives, or friends }\end{array}$} & Yes & $1331 / 2321(57.4)$ & Rarely & $811(34.9)$ \\
\hline & & & Sometimes & $315(13.6)$ \\
\hline & & & Often & $99(4.3)$ \\
\hline & & & Very often & $106(4.6)$ \\
\hline & No & $990 / 2321(42.7)$ & & \\
\hline
\end{tabular}


level of the parents had no significant relationship with the VTS scores of the adolescents. However, adolescents who had a mother or a father with lower than high school level of education had significantly lower AWS scores $(p<0.001)$. Adolescents who described violence as emotional, restriction of social interaction, sexual and verbal had significantly lower VTS scores and higher AWS scores $(p<0.05)$. Adolescents who described violence as economic had significantly higher VTS scores and higher AWS scores $(p<0.05)$.

Additionally, the relationships of the VTS and AWS scores with the experiences of violence that the adolescents had are given in Table 4. The AWS scores decreased and the VTS scores increased with increased experiences of violence ( $p<0.001$ for both scores).
Finally, based on the stepwise multiple logistic regression results, $14 \%$ of the variation in tendency towards violence could be explained with the AWS, sex, received attempted violence from family members, relatives, or friends, and observed attempted violence towards family members, relatives, or friends (Table 5). The most prominent effect was seen when there was an observed attempt of violence towards family members, relatives or friends (coefficient $=2.12$ ).

\section{Discussion}

In the current study, more than one third of the adolescents had been exposed to physical, verbal, emotional or sexual violence. More than half had witnessed violence related to their family members, relatives, or close

\begin{tabular}{|c|c|c|c|c|}
\hline Demographic features & $\begin{array}{l}\text { Violence Tendency } \\
\text { Scale }\end{array}$ & $\boldsymbol{P}$ & $\begin{array}{l}\text { Attitudes towards } \\
\text { Women Scale }\end{array}$ & $\mathbf{P}$ \\
\hline \multicolumn{5}{|l|}{ Sex } \\
\hline Female & $46(10.05)$ & $<0.001$ & $42(5.27)$ & $<0.001$ \\
\hline Male & $49(11.15)$ & & $37(6.67)$ & \\
\hline \multicolumn{5}{|l|}{ Economic status } \\
\hline Middle/ high & $47(10.37)$ & $<0.001$ & $40(6.24)$ & $<0.001$ \\
\hline Low & $54(13.90)$ & & $37(8.53)$ & \\
\hline \multicolumn{5}{|l|}{ Maternal education level } \\
\hline Lower than high school & $48(11.04)$ & 0.194 & $39(6.51)$ & $<0.001$ \\
\hline High school or higher & $47(10.30)$ & & $41(6.17)$ & \\
\hline \multicolumn{5}{|l|}{ Paternal education level } \\
\hline Lower than high school & $47(10.01)$ & 0.692 & $39(6.66)$ & $<0.001$ \\
\hline High school or higher & $47(10.44)$ & & $41(6.12)$ & \\
\hline \multicolumn{5}{|l|}{ Types of violence } \\
\hline \multicolumn{5}{|l|}{ Physical } \\
\hline Yes & $47(10.43)$ & 0.059 & $40(6.32)$ & $<0.001$ \\
\hline No & $49(13.33)$ & & $36(6.20)$ & \\
\hline \multicolumn{5}{|l|}{ Emotional } \\
\hline Yes & $47(10.31)$ & 0.004 & $41(6.11)$ & $<0.001$ \\
\hline No & 49 (11.97) & & $37(6.56)$ & \\
\hline \multicolumn{5}{|l|}{ Economical } \\
\hline Yes & $48(10.70)$ & 0.045 & $41(6.46)$ & $<0.001$ \\
\hline No & $47(10.67)$ & & $40(6.37)$ & \\
\hline \multicolumn{5}{|c|}{ Restriction of social interaction } \\
\hline Yes & $47(10.53)$ & 0.171 & $41(6.16)$ & $<0.001$ \\
\hline No & $48(10.85)$ & & $39(6.46)$ & \\
\hline \multicolumn{5}{|l|}{ Sexual } \\
\hline Yes & 47 (10.44) & 0.025 & $41(6.27)$ & $<0.001$ \\
\hline No & 48 (11.50) & & $37(6.31)$ & \\
\hline \multicolumn{5}{|l|}{ Verbal } \\
\hline Yes & $47(10.38)$ & 0.003 & $41(6.19)$ & $<0.001$ \\
\hline No & 49 (11.78) & & $37(6.48)$ & \\
\hline
\end{tabular}




\begin{tabular}{|c|c|c|c|c|}
\hline & Violence Tendency Scale & $\boldsymbol{P}$ & $\begin{array}{l}\text { Attitudes towards } \\
\text { Women Scale }\end{array}$ & $\mathbf{P}$ \\
\hline \multicolumn{5}{|c|}{$\begin{array}{l}\text { Took part in violence directed towards family members, } \\
\text { relatives, or friends }\end{array}$} \\
\hline Never & $44(9.65)$ & \multirow[t]{5}{*}{$<0.001$} & $40(5.90)$ & \multirow[t]{5}{*}{$<0.001$} \\
\hline Rarely & $48(9.010$ & & $40(6.06)$ & \\
\hline Sometimes & $52(9.50)$ & & $38(6.68)$ & \\
\hline Usually & $58(11.32)$ & & $38(6.94)$ & \\
\hline Very often & $64(12.86)^{\mathrm{a}}$ & & $31(9.10)$ & \\
\hline \multicolumn{5}{|c|}{$\begin{array}{l}\text { Violence attempts received from family members, relatives, } \\
\text { or friends }\end{array}$} \\
\hline Never & $45(10.52)$ & \multirow[t]{5}{*}{$<0.001$} & $40(6.30)$ & \multirow[t]{5}{*}{$<0.001$} \\
\hline Rarely & $47(9.28)$ & & $40(5.89)$ & \\
\hline Sometimes & $50(10.73)$ & & $40(6.44)$ & \\
\hline Usually & $52(10.30)$ & & $39(6.58)$ & \\
\hline Very often & $63(14.20)^{\mathrm{a}}$ & & $30(9.09)$ & \\
\hline \multicolumn{5}{|c|}{$\begin{array}{l}\text { Observed violence directed towards family members, } \\
\text { relatives, or friends }\end{array}$} \\
\hline Never & $45(10.53)$ & \multirow[t]{5}{*}{$<0.001$} & $40(6.31)$ & \multirow[t]{5}{*}{$<0.001$} \\
\hline Rarely & $46(9.10)$ & & $41(5.58)$ & \\
\hline Sometimes & $49(10.49)$ & & $40(6.55)$ & \\
\hline Usually & $50(11.20)$ & & $39(6.68)$ & \\
\hline Very often & $58(14.50)^{\mathrm{a}}$ & & $34(9.17)$ & \\
\hline \multicolumn{5}{|c|}{$\begin{array}{l}\text { Observed attempted violence towards family members, } \\
\text { relatives, or friends }\end{array}$} \\
\hline Never & $45(9.97)$ & \multirow[t]{5}{*}{$<0.001$} & $40(6.17)$ & \multirow[t]{5}{*}{$<0.001$} \\
\hline Rarely & $46(9.46)$ & & $40(5.80)$ & \\
\hline Sometimes & $50(10.32)$ & & $39(6.45)$ & \\
\hline Usually & 51 (11.79) & & $38(7.24)$ & \\
\hline Very often & $59(14.16)^{\mathrm{a}}$ & & $33(8.69)$ & \\
\hline
\end{tabular}

${ }^{a}$ This subgroup had significant results in the post hoc Bonferroni analysis.

friends. Adolescents who had experienced violence directed towards themselves or close relations had a higher tendency to act violently themselves. In the study of Özgür et al., among high school students, $10 \%$ of the adolescents experienced physical violence directed towards themselves, and in the same study, only $45 \%$ of the students defined psychological violence as violence (22). In the current study, the number of adolescents who experienced only physical violence was not available because all types of violence were included while asking about perceptions and experiences of violence. When considering all types of violence, the frequency of perceived violence was almost 5 times higher than that in the study of Özgür et al., although that study focused on physical violence.

More than half of our respondents considered psychological problems, alcohol, or perceptions of honour as the main reasons for the experienced violence. Males had a greater tendency towards violence and a less profeminist attitude when compared to females. A greater tendency to resort to violence by male when compared to female adolescents was confirmed by other studies
(16,22-24). These findings can be explained by the differences in the upbringings of male and female children, and the given social roles during that time $(24,25)$.

We found that conservative and traditional attitudes towards women were associated with a higher tendency towards violence among adolescents. The finding of a negative relation between attitudes towards women and the tendency towards violence is supported by the literature. Similar findings were reported by Çetinkaya (16). Reyes et al. reported that the perception of gender roles was associated with dating violence among adolescents (17), which was also determined among Canadian adolescents in the study of Sears et al. and in Chinese adolescents by Shen et al. $(18,19)$. In many other studies, it has been shown that masculinity and domination by men are both linked to the perpetration of violence by men $(20,21)$.

The strength of this study was that it was based on a large well-chosen sample from the whole population in a large city in Western Turkey. However, there were also some limitations to the study. First, considering 


\begin{tabular}{|c|c|c|c|c|c|}
\hline Independent variable & Odds ratios & $\begin{array}{c}95 \% \\
\text { confidence } \\
\text { interval }\end{array}$ & $\begin{array}{l}\text { Standard } \\
\text { error }\end{array}$ & t ratio & $\mathbf{P}$ \\
\hline Attitudes towards women score & 1.40 & $1.30-1.54$ & 0.41 & 2.86 & $<0.001$ \\
\hline Sex & 4.95 & $2.12-11.59$ & 0.41 & 2.86 & $<0.001$ \\
\hline $\begin{array}{l}\text { Violence attempts received from family members, } \\
\text { relatives, or friends }\end{array}$ & 4.17 & $2.46-7.10$ & 0.24 & 16.39 & $<0.001$ \\
\hline $\begin{array}{l}\text { Observed violence attempts towards family members, } \\
\text { relatives, or friends }\end{array}$ & 8.33 & $5.37-13.07$ & 0.22 & 4.23 & $<0.001$ \\
\hline Intercept & $1.44 \times 10^{13}$ & $\begin{array}{c}1.65 \times 10^{12}-1.19 \\
\times 10^{14}\end{array}$ & 1.02 & 30.01 & $<0.001$ \\
\hline
\end{tabular}

the population of the whole country and the diversity of ethnicities, traditions, and social lives in each region, results based on only 1 city cannot be generalized to the entire population. A second and more serious limitation was the social bias in the recruitment in high schools. Our data represented the views of adolescents attending high schools in Western Turkey, who traditionally have a higher economic status when compared with the rest of the country. A deeper understanding would be gained by the inclusion of low-income adolescents from other regions. Third, the study was cross-sectional and therefore could not show causal relationships between the tendency towards violence and attitudes towards women. Fourth, the perceptions of the different types of violence were investigated using words such as physical and emotional. Adolescents might have interpreted these terms differently and that might have resulted in an underestimation of the true prevalence of violence. A better approach would be to give case definitions and ask adolescents if they considered the related scenarios as violence.

\section{Conclusion}

One in three adolescents experienced or observed violence in their immediate environments. Thus, psychological screening may be performed to recognize recipients and observers of violence and support them medically and socially. Since there was a negative correlation between the attitudes towards women and the tendency towards violence, improving either one of these may have a positive effect on the other. From a long-term perspective, policies that protect and advocate the rights of adolescents, which can prevent the reoccurrence of violence, should be further developed and then successfully implemented.

\section{Funding: None.}

Competing interests: None declared.

\section{Tendance à la violence et rôles sociaux : une étude descriptive parmi les lycéens en Turquie \\ Résumé}

Contexte : La violence touche plus de la moitié des femmes dans le monde et la perception des rôles sociaux joue un rôle important à cet égard. L'adolescence est une période de développement sensible dans la vie d'un individu. Il est donc important de comprendre la perception de la violence et de changer l'acceptation de cette dernière parmi les adolescents.

Objectifs : Aborder les expériences des adolescents en matière de violence et sa relation avec les attitudes envers les femmes.

Méthodes: La présente étude descriptive, comprenant 2321 lycéens, a été menée à Izmir (Turquie) entre mai et août 2015. Nous avons utilisé un questionnaire pour recueillir des données sur les informations sociodémographiques et les perceptions des adolescents à l'égard de la violence. Les échelles concernant la tendance à la violence et les attitudes envers les femmes ont été appliquées pour montrer les perceptions des adolescents au sujet des rôles sociaux.

Résultats: Un tiers des adolescents ont déclaré avoir été exposés à une forme de violence. Plus de la moitié ont été témoins de violences contre des membres de leur famille, des parents ou des amis proches. Les attitudes conservatrices et traditionnelles à l'égard des femmes étaient associées à une tendance plus élevée à la violence chez les adolescents.

Conclusions: Pour mettre fin à la violence à l'égard des femmes, les actions de santé publique devraient être centrées sur la population jeune et sa représentation des rôles sociaux. 


\section{الاتجاه نحو العنف والأدوار الاجتماعية: دراسة وصفية بين طلاب المدارس الثانوية في تركيا \\ توجبا كاليسكان، كاندان قندير، حمزة أكيول، نيلز كير، عزيزة جولدوال}

الخلاصة

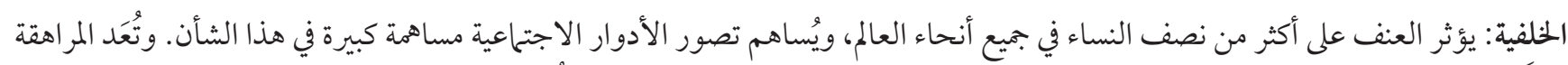

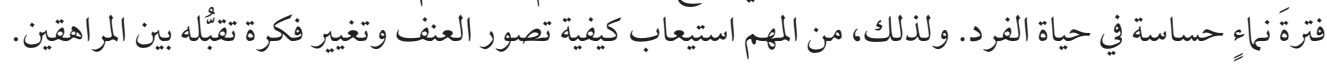

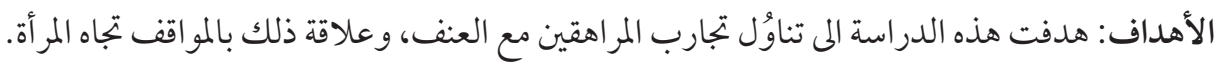

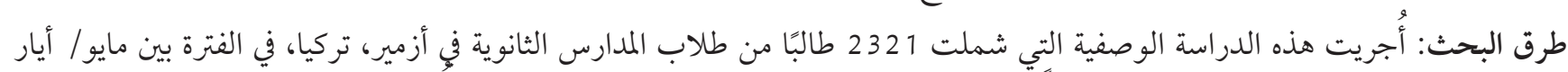

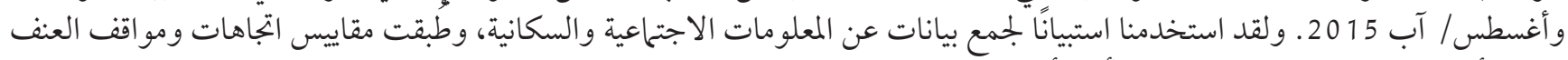

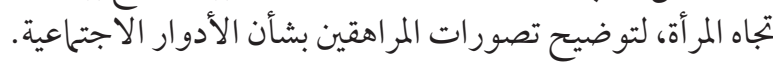

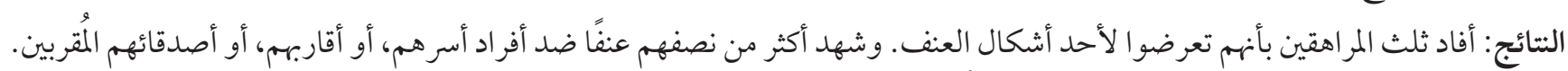

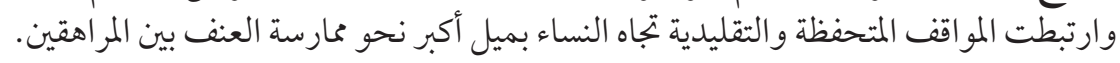

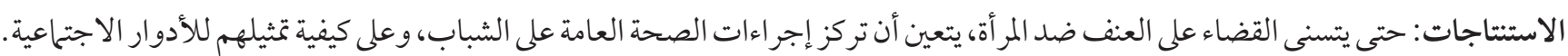

\section{References}

1. Garcia-Moreno C, Jansen HA, Ellsberg M, Heise L, Watts CH. Prevalence of intimate partner violence: Findings from the WHO multi-country study on women's health and domestic violence. Lancet. 2006 Oct 7;368(9543):1260-9. https://doi.org/10.1016/ So140-6736(06)69523-8 PMID: 1702773

2. Butchart A, Mikton C, Dahlberg LL, Krug EG. Global status report on violence prevention 2014. Inj Prev. 2015 Jun;21(3):213. https:// doi.org/10.1136/injuryprev-2015-041640 PMID:25995201

3. Tjaden P, Thoennes N. Prevalence, incidence, and consequences of violence against women: findings from the National Violence Against Women Survey, research in brief. Rockville, MD: National Criminal Justice Reference Service; 1998.

4. Violence prevention. Risk and protective factors [website]. Atlanta: Centers for Disease Control and Prevention https://www.cdc. gov/violenceprevention/youthviolence/riskprotectivefactors.html, accessed 24 December 2020)

5. Craig W, Harel-Fisch Y, Fogel-Grinvald H, Dostaler S, Hetland J, Simons-Morton B, et al. A cross-national profile of bullying and victimization among adolescents in 40 countries. Int J Public Health. 2009 Sep;54(Suppl 2):216-24. https://doi.org/10.1007/ s00038-009-5413-9 PMID:19623475

6. Global Health Observatory (GHO) data 2015. Geneva: World Health Organization; 2015.

7. Stöckl H, March L, Pallitto C, Garcia-Moreno C. Intimate partner violence among adolescents and young women: prevalence and associated factors in nine countries: a cross-sectional study. BMC Public Health. 2014 Jul 25;14(1):751. https://doi.org/10.1186/14712458-14-751 PMID: 2505942

8. Wilkins N, Tsao B, Hertz MF, Davis R, Klevens J. Connecting the dots: an overview of the links among multiple forms of violence. Inj Prev. 2014;21(1):A2 https://doi.org/10.1136/injuryprev-2015-041602.4

9. Altinay AG, Arat Y. Violence against women in Turkey: a nationwide survey. Istanbul: Punto; 2009.

10. Celbiş O, Karaoğlu L, Eğri M, Özdemir B. Violence among high school students in Malatya: a prevalence study. Turk J Med Sci. 2012;42(2):343-50. https://doi.org/10.3906/sag-1102-1394

11. Yavuz M, Atan Y, Atamer T, Gölge Z. [Evaluation of physical violence for high school students: violence in school and in family and violence by the student]. Adli Bilim Derg. 2003;2(3):35-43 (in Turkish).

12. Levy PS, Lemeshow S. Sampling of populations: methods and applications. Wiley; 2013.

13. Haskan Ö, Yıldırım İ. [Development of Violence Tendency Scale]. Eğitim Ve Bilim. 2012;37(163):165-77 (in Turkish).

14. Spence JT, Helmreich R, Stapp J. A short version of the Attitudes toward Women Scale (AWS). Bull Psychon Soc. 1973;2(4):219-20. https://doi.org/10.3758/BF03329252

15. Delevi R, Bugay A. Assessing reliability and validity of the 15-item short version of the Attitudes toward Women Scale (AWS) among Turkish students. J Int Women Stud. 2013;14(1):263-72.

16. Çetinkaya SK. [The examination of the relationship between tendency of violence and gender roles attitudes among the university students]. Nesne Psikol Derg. 2013;1(2):21-43 (in Turkish).

17. Reyes HLM, Foshee VA, Niolon PH, Reidy DE, Hall JE. Gender role attitudes and male adolescent dating violence perpetration: normative beliefs as moderators. J Youth Adolesc. 2016 Feb;45(2):350-60. https://doi.org/10.1007/s10964-015-0278-0 
18. Sears HA, Byers ES, Price EL. The co-occurrence of adolescent boys' and girls' use of psychologically, physically, and sexually abusive behaviours in their dating relationships. J Adolesc. 2007 Jun;30(3):487-504. https://doi.org/10.1016/j.adolescence.2006.05.002 PMID:16884766

19. Shen AC-T, Chiu MY-L, Gao J. Predictors of dating violence among Chinese adolescents: the role of gender-role beliefs and justification of violence. J Interpers Violence. 2012 Apr;27(6):1066-89. https://doi.org/10.1177/0886260511424497 PMID:22328647

20. Jewkes R, Flood M, Lang J. From work with men and boys to changes of social norms and reduction of inequities in gender relations: a conceptual shift in prevention of violence against women and girls. Lancet. 2015 Apr 18;385(9977):1580-9. https://doi. org/10.1016/So140-6736(14)61683-4

21. Jewkes R, Sikweyiya Y, Morrell R, Dunkle K. Gender inequitable masculinity and sexual entitlement in rape perpetration South Africa: findings of a cross-sectional study. PloS One. 2011;6(12):e29590. https://doi.org/10.1371/journal.pone.0029590 PMID:22216324

22. Özgür G, Yörükoğlu G, Baysan-Arabacı L. [High school student's perception of violence, level of tendency to violence and effective factors]. Psikiyatri Hemşireliği Derg. 2011;2(2):53-60 (in Turkish).

23. Campbell A. Sex differences in direct aggression: what are the psychological mediators? Aggress Violent Behav. 2006;11(3):23764. https://doi.org/10.1016/j.avb.2005.09.002

24. Alikasifoglu M. Violent behaviour among Turkish high school students and correlates of physical fighting. Eur J Public Health. 2004 Jun 1;14(2):173-7. https://doi.org/10.1093/eurpub/14.2.173 PMID:15230504

25. Eagly AH. Sex differences in social behavior: a social-role interpretation. Psychology Press; 2013. 